and associations. He strongly recommends Esperanto as a neutral language for this purpose, remarlsing that it is already well known both in Germany and in Austria-Hungary. Moreover, classes for Esperanto have been formed in many internment camps among both civilian and military prisoners. The knowledge of this auxiliary language has enabled prisoners of different nationalities to converse together. It is, indeed, to be expected that prisoners in a foreign countrv should keenly realis $z$ the advantages of a language common to themselves and their gaolers.

THE fourth annual meeting of the conference $\mathrm{cn}$ New Ideals in Education was held, August I4 to $2 \mathrm{I}$, at Bedford College, London, under the presidency of the Earl of Lytton, and was, like its predecessors, largely attended by persons representative of a wide range of educational interests, lay and professional. The main subject of debate was the problems pre. sented by the system of universal continuation schools now under the consideration of Parliament. The dis cussion was opened by the President of the Board of Education himself, who spoke of the continuation schools as a potential great "University of England," the best and most durable national memorial of the war, and invited missionary effort to commend the principles of his present Bill to popular opinion, and to secure its smooth working if it should be passed. In the subsequent sessions the oonference considered the special problems that confront the urban and rural continuation schools respectively. With regard to the former, it was agreed that the main difficulty lies in the treatment of boys and girls condemned to monotonous unskilled labour, and that, in dealing with this great section of our juvenile population, educational cannot be separated from social and industrial eform.

Tine report of the committee appointed by the NorthEast Coast Institution of Engineers and Shipbuilders upon the education of apprentices has now been issued, and has been accepted generally by the other engineering and shipbuilding associations in the north-east district. The scheme in brief provides for elementary education up to twelve and a half years of age approximately, followed by three years' full time at a junior technical school. The bulk of the boys $(a)$ then proceed to ordinary apprenticeship with two or three halfdays per week at continuation classes up to eighteen years of age; the best $(b)$ are to spend half-time per week in the works and the other half in the technical college up to the same age. Group $(a)$ then proceeds to ordinary apprenticeship with optional evening classes. Group $(b)$ is divided again at eighteen years of age, the majority proceeding to ordinary apprenticeship with optional evening classes, while those of special quality proceed to the full applied science degree course leading to the B.Sc. in engineering or naval architecture. The details of the scheme comprise mañy interesting features. Junior day technical schools should be regarded as a distinct type of higher school, in no sense inferior to a secondary school; this point is to be urged upon the Board of Education by a deputation representing the Institution. An advisory committee is to be appointed to be associated with the management of the schools in a consultative capacity. Youths passing out of these schools are to have preferential treatment in the matter of appointment to apprenticeship. The latter point is of great importance, and if adopted throughout the country will be instrumental in the suppression of the premium system, and also of the method which some firms adopt of taking as apprentices without premiun those lads only who are sons of employees, irrespective of their previous training. The scheme is excellent on the whole, and will provide facilities for any intelligent lad possessing grit to rise to the top of the educational ladder and to qualify for the highest posts no matter how lowly he may start. There is just one point open to criticism. The best lads who are selected for university courses will be handicapped at matriculation if no foreign language is taught prior to the age of sixteen. It would be well to include, say, two hours per week in the junior technical school curriculum; this would have the effect of bringing the products of these schools into line with secondary-school boys starting apprenticeship at sixteen. The report is well worth studying by all interested in education.

\section{SOCIETIES AND ACADEMIES. PARIS.}

Academy of Sciences, July 30.- M. Paul Appell in the chair.-The president announced the death of M. F.C. Grand'Eury, correspondant of the section of botany.G. Bigourdan: The propagation of the sound-wave produced by gun-fire to great distances. Direct determinations of the velocity of sound in the air could be made to-day over distances nearly ten times those utilised in the earlier experiments made between 1736 and $1822 .-H$. Le Chatelier: The tempering of steel. Summarising recent researches by Portevin, Chevenard, and Dejean, the author concludes that, starting with the eutectoid with $0: 8$ per cent. carbon, initial state austenite, the final state may be perlite with slow cooling, troostite, martensite, or austenite being the final products as the rate of cooling is increased. The last case can only be practically realised in the presence of 2 per cent. of manganese or a slightly higher propurtion of nickel.-M. Balland: The alterations of biscuit bread. The flour used is the same as that of which ordinary bread is made, but it is baked in a cooler oven for a longer time. It has a thicker crust, highly resistant to the action of external influences, and keeps good for from fifteen to twenty days. -A. Nodon: Observations on the eclipse of the moon of July 4, 1917. The observations were made at Bordeaux under good atmospheric conditions, and the results appear to indicate a luminosity due to the surface of the moon.-E. Belot: The physical and ballistic history of the lunar volcanoes.-M. Portevin : The carburation of iron by alkaline cyanides and cyanates. At temperatures of $750^{\circ} \mathrm{C}$. and $900^{\circ} \mathrm{C}$. the addition of a proportion of cyanate to potassium cyanide results in a considerable increase in the amount of carbon taken up by the iron.-P. Dejean : The formation of troostite and martensite.-A. Colani : The action of metaphosphoric acid upon the oxides of molybdenum. At a red heat metaphosphoric acid acts upon $\mathrm{MoO}_{3}$, giving a slight reduction and evolution of oxygen.- $\mathrm{H}$. Travers : The rapid estimation of manganese and chromium in metallurgical products. The method is based on oxidation with ammonium persulphate and subsequent titration with sodium arsenite and is applicable to certain chrome steels.-L. Vialleton: Ontogenic relations of the pelvic and thoracic bands in the tetrapod vertebrates.-A. Lécaillon: The signification of the colour-changes normally produced in certain non-impregnated eggs of Bombyx mori and the formation, in this species, of true caterpillars of parthenogenetic origin.-H. Colin : The antiseptic properties of nitrous fumes. In the absence of oxygen, nitric oxide is devoid of antiseptic properties. The contrary results obtained by Priestley were due to nitric acid produced by the simultaneous presence of air and water.-P. Portier: Researches on symbiotic micro-organisms in the animal series.-MM. Weinburg and P. Séquin: Serotherapy of gas gangrene in man. An account of the favourable results obtained by a mixed serum.-P. Armand-Delille : Remarks on the parasitological aspects of malaria contracted in Macedonia. 
August 6.-M. Paul Appell in the chair.-A. Lacroix: The granulated rocks of a leucitic magma studied with the aid of the holocrystalline blocks of the Somma.-G. Humbert: The continued fraction of Stepher Smith.-H. Le Chatelier and B. Bogitch: The refractory properties of silica. Wark supplementary to results published in an earlier paper (C.R., 1917, p. 64). A brick made from refractory clay, crushed at a temperature of $\mathrm{r}_{500}^{\circ} \mathrm{C}$., flattened and showed rounded edges, whilst, with silica, the first action of the pressure produced no appreciable effect. On breaking the test piece by increasing the pressure, the pieces corresponded in shape with those normally observed with hard materials. Good silica bricks contain between 3 per cent. and 5 per cent. of basic oxides, and the weight of sulphates obtained after attack by hydrofluoric and sulphuric acids is between 8 per cent. and I4 per cent. Results are given of the resistance to crushing after one hour at $1600^{\circ} \mathrm{C}$. of a number of good commercial silica bricks.-P. Sabatier and G. Gaudion: A new case of reversible catalysis: direct formation of nitriles starting from amines of the same carbon chain. Benzylamine passed in the state of vapour over reduced nickel at $300^{\circ} \mathrm{C}$. to $350^{\circ} \mathrm{C}$. is converted into benzonitrile, toluene, and ammonia, one-third of the amine being converted into the nitrile. isoAmylamine behaves similarly.- $\mathrm{H}$. Hildebrandson : Some remarks on the possible influence of violent cannonades on rainfall.- J. Guillaume : Observations of the sun, made at the Observatory of Lyons, during the first quarter of $19 \mathrm{I} 7$. Observations were made on sixty-four days, and are grouped in tables giving the number of spots, their distribution in latitude, and the distribution of the faculæ in latitude.-A. Colani : Study of the system : water, uranyl oxalate, ammonium oxalate.-E. Rengade: The purification of salts by clairçage or by fractional crystallisation. The word clairçage is applied to the displacement, by means of water or an appropriate solvent, of the impure mother liquor impregnating the crystals. The case of ammonium nitrate mixed with a small proportion of sodium chloride is discussed in detail, the reactions being followed microscopically.-A. Cochain : The existence of an approximate centre of symmetry in the figure formed by the directing lines of the Alpine system. 'The tectonic interpretation of this quasi-symmetry.-J. Deprat : The frontal zone of the preyunnanaise sheets in the regions of Bao-lac and Cao-bang.-J. Amar: The physiopathology of effort. Effort is defined as a maximum muscular action generally sustained, sometimes instantaneous. The present paper deals with the relations between respiration and effort both in the normal and pathological states.-O. Bailly : Does the law of mass-action govern diastatic reactions? Earlier work has been in the direction of measuring the reaction-velocities of diastatic reactions: the author gives reasons for preferring to study the final equilibrium state, and for this it is necessary to choose reversible diastatic reactions carried out in homogeneous media. The case chosen is the synthesis and hydrolysis of $\beta$-methylglucoside, making use of the experimental data of Em. Bourquelot and Em. Verdon, and here the experimental values and those calculated from the law of mass-action are in good agreement.

\section{CAPE Town.}

Royal Society of South Africa, June 20.-Dr. L. Péringuey, president, in the chair.-H. V. Exner: A case of hermaphroditism. A description of the body of a person of unsound mind who had the outward appearance of a Kaffir girl.-I. B. Pole Evans: The genus Terfezia. A truffle from the Kalahari. Chœromyces, a truffle hitherto unknown to Africa, has recently been reported from South Africa. It was pointed out that the best known South African truffles belong to the genus Terfezia. The distinction between Chœromyces and Terfezia was indicated, and a description given of a truffle ( $T$. Claveryi, Chat.) recently sent from the Griqualand West district in the Kalahari.

\section{BOOKS RECEIVED.}

The Theory and Use of Indicators : An Account of the Chemical Equilibria of Acids, Alkalies, and Indicators in Aqueous Solution, with Applications. By Dr. E. B. R. Prideaux. Pp. vii +375 . (London: Constable and $\mathrm{Co}$, Ltd.) 12s. $6 d$. net.

Bureau Internaticnal des Poids et Mesures. La Mesure Rapide des Bases Géodésiques. By J. R. Benoît and C. E. Guillaume. Cinquième édition. Pp. 283. (Paris: Gauthier-Villars et Cie.)

The Thyroid Gland in Health and Disease. By Dr. McCarrison. Pp. xvii +286 . (London: Bailliere, Tindall, and Cox.) 12s. $6 d$. net.

Stanford's Half-inch Map of the Battle Front: Ostend, Zeebrugge, Bruges. (London: E. Stanford, Ltd.) $2 s .6 d$.

Laws of Physical Science. By Dr. E. F. Northrup. Pp. vii + 2 ro. (Philadelphia and London: J. B. Lippincott, Ltd.) 8s. 6 d. net.

Standard Method of Testing Juvenile Mentality by the Binet-Simon Scale. By N. J. Melville. Pp. xit 142. (Philadelphia and London: J. B. Lippincott, Ltd.) $8 s .6 d$. net.

Standard Methods of Chemical Analysis. By W. W. Scott and others. Pp. xxxi $+864+$ plates iii. (New York: D. Van Nostrand Co.; London: Crosby Lockwood and Son.) 3os. net.

\section{CONTENTS.}

PAGE

New Books on Plants ........... 5ar Is the Anglo-Saxon Doomed? By A. K. . . . $5^{\circ}$ Another Text-book of Histology. By E. W. M. . ${ }^{C}$

Our Bookshelf ............. . 503 Letters to the Editor:-

The Terminology of Parthenogenesis,-Sir E. Ray

Lankester, K.C.B., F.R.S. . . . . . . 504

The Scandinavian Languages. - T. R. R. S. . . . . 505 The Civil Aerial Transport Committee. (Illus-

trated.) By Sir G. Greenhill, F.R.S. . . . . 506 The "Isle of Wight" Bee Disease ...... 507 Notes . . . . . . . . . . . . . 508 Our Astronomical Column:-

The Commencement of the Astronomical Day . . . 512 Observations of Mira Ceti ........ 512

Eclipsing Variables .......... . $5^{12}$

Drum-fire ............. . . 513 The Treatment of War Wounds. (Illustrated.) By

Col. Sir Almroth E. Wright, C.B., F.R.S. . . . . $5^{14}$

University and Educational Intelligence .... 518

Societies and Academies . . . . . . . . 519

Books Received . . . . . . . . 520

Editorial and Publishing Offices:

MACMILLAN AND CO., LTD.,

ST. MARTIN'S STREET, LONDON, W.C.2.

Advertisements and business letters to be addressed to the Publishers.

Editorial Commurications to the Editor

Telegraphic Address: Phusts, LONDON.

Telephone Number: GrRrard 8830.

NO. 2495, VOL. 99] 